\title{
The Determination of Brick Provenance and Technology Using Analytical Techniques from the Physical Sciences.
}

\author{
S. Pavía \\ Department of Civil, Structural and Environmental Engineering, Trinity College, Dublin. Ireland.
}

KEYWORDS: brick, technology, provenance, Dublin, petrographic microscopy, SEM/EDX, XRD, mortar.

\begin{abstract}
This work applies established analytical techniques of physical sciences to Irish brick in order to gather evidence of ceramic technologies, provenance and sources of raw materials. Petrographic microscopy, X-ray diffractometry and scanning electron microscopy with an energy dispersive Xray diffraction attachment were used to study the brick of Rathfarham Castle, Dublin, built c.1618, where clay brick was introduced in 1771. Local clay was fired in the laboratory and analysed in a similar manner. The petrography of the pointing mortar was studied in order to gather evidence of ceramic provenance. This paper concludes that the brick was hand- moulded with a silica-based, predominantly non-calcareous clay of glacial origin gathered locally, including fluxes and a high percentage of non-plastic material. The mineralogy and petrography of the brick together with the presence of pebbles and a coarse-matrix suggest that the raw clay was probably gathered from a glacial deposit. The presence of abundant pebbles and colour inhomogeneities suggests a lack of processing of the raw clay. The brick was probably fired in clamps at top firing temperatures of 750 to above $900{ }^{\circ} \mathrm{C}$. Transformation of limestone temper involving breakdown of calcite and generation of calcium silicates, new-formation of plagioclase, high-temperature quartz, hematite and spinel were evidenced. The presence of spinel in 'hot spots' indicates that fuel was added to the raw clay in order to assist firing.
\end{abstract}

\section{INTRODUCTION}

Ceramic material constitutes a historic record. Physical sciences applied to products of the clay and silicate industries allow investigating ceramic technologies, provenance, sources of raw materials and trade or exchange patterns. A number of contemporary scientists including Firman, Freestone, Dunhan, Heimann, Iberg, Maggetti, Middleton, Peters, Tite and Veniale have applied physical sciences to the study of clay and silicate materials. This study stands on work by these and other authors.

Rathfarham Castle is situated on a promontory overlooking the valley of the River Dodder, in the southwest of Dublin city. Currently, it lays within the city limits, approximately 4 miles from the city centre. Rathfarham Castle is a seven bay, threestorey over basement building, with outstanding square plan flanking towers

${ }^{1}$ This paper is dedicated to the memory of Dr. R. J. Firman, a wise man and a source for inspiration. 
attached at each corner. The majority of Rathfarham Castle was originally built of rubble limestone before 1618 and rendered with a lime mortar. Clay brick was introduced in 1771, when the castle was remodelled and a semi-circular extension added to the East. This is one of the earliest uses of brick in Ireland.

It has traditionally been said that most historic clay brick in Ireland was imported from Britain and entered the country as ships ballast through the large harbours of Dublin and Cork. A certain amount of brick was certainly imported from places such as Bridgewater in Britain (Wyse-Jackson
1993), and occasionally, some brick was imported for particular works from places such as The Netherlands (Roundtree 1999). However, research on the history of Irish brick (Roundtree 1999) as well as scientific studies on the provenance of brick (Pavía $1999^{1}$, Pavía $1999^{2}$, Pavía et al. 2000 , Pavía et al. 2004) suggest that a significant amount of Irish brick was made locally. Raw material for brick making occurs in every county in Ireland and most major cities and towns were probably supplied by either adjacent brick yards or brick transported from other localities by ship or barge (Pavía et al. $2000^{2}$ ).

Figure 1-Rathfarham Castle. From right to left: front and back elevations on top and East and West views at the bottom. Drawings by Gay Daly.

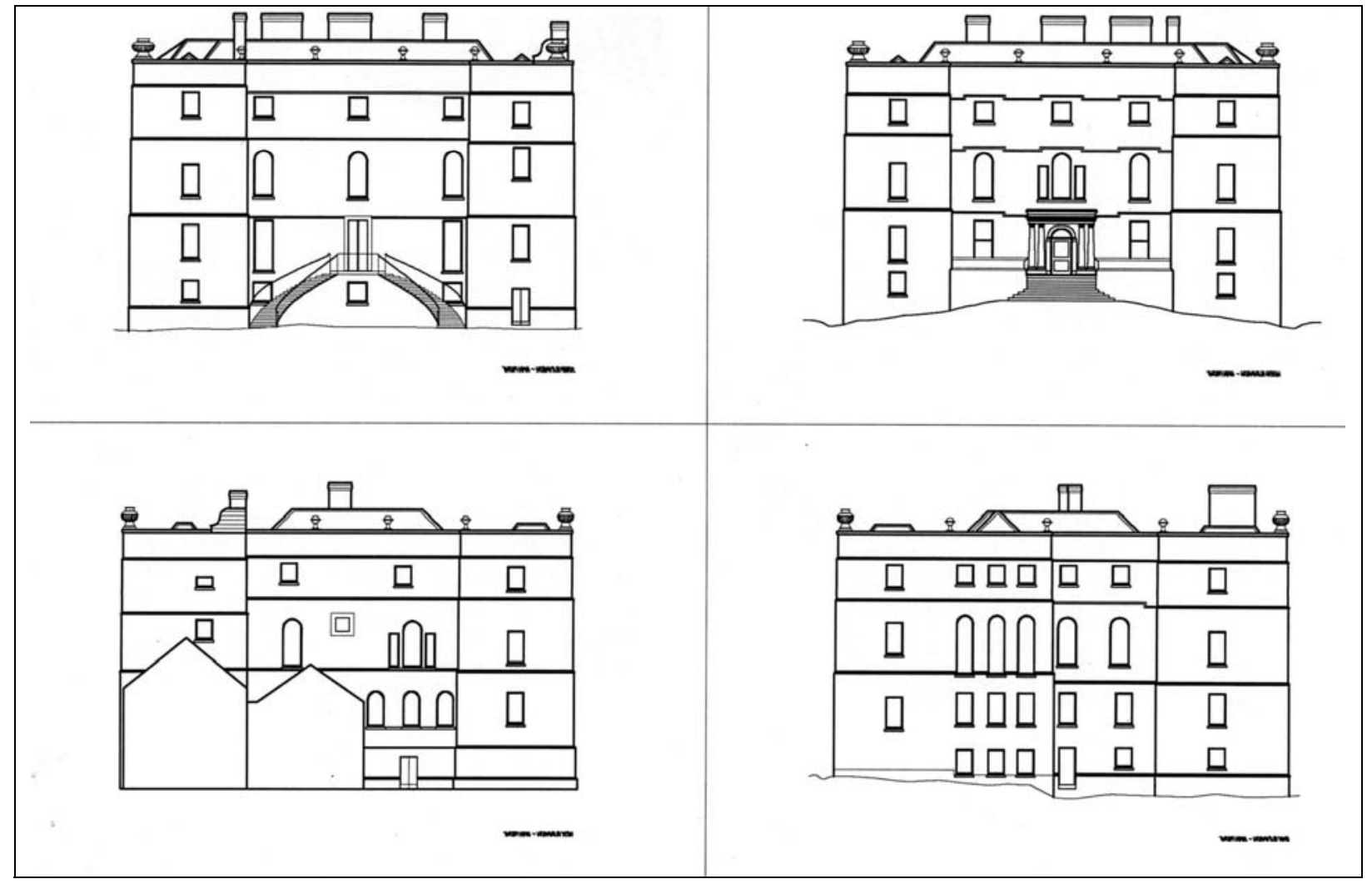




\section{OBJECTIVE}

The aim of this study is to determine firing technologies, provenance and sources of raw materials for a particular historic Irish brick. To this aim, established scientific methods and analytical techniques of physical science
(Heimann (1982); Tite et al. (1982) ${ }^{1}$; Veniale 1990; Freestone \& Middleton (1991); Dunham (1992); Maggetti (1994); Freestone (1995)) were applied to the brick, local clay and lime mortars of Rathfarham Castle.

\section{METHODOLOGY}

Analytical techniques including petrographic microscopy, X-ray diffractometry (XRD) and scanning electron microscopy (SEM) with an energy dispersive $\mathrm{X}$-ray microanalysis attachment (EDX) were used to study the Rathfarham brick and the local fired clay. Clay was collected from a lake area $700 \mathrm{~m}$ south of the Castle and fired in a furnace, in an oxidizing atmosphere, at temperatures of $700,800,900,1000$ and $1200^{\circ} \mathrm{C}$. The mineralogy was analysed by XRD (the powder method) with a diffractometer Philips PW 1710 using $\mathrm{Cu} \mathrm{K \alpha}$ radiation with a voltage of $40 \mathrm{kV}$. and an intensity of $40 \mathrm{~mA}$. The area was scanned between 2 and 60 degrees 2 $\theta$. In order to study ceramic provenance, the mineralogy of the brick was compared to that of the fired clay.

Petrographic analysis of the brick temper and the brick pointing mortar were undertaken to identify local or foreign production. 'By definition, temper includes all phases with a diameter greater than $0.015 \mathrm{~mm}$. The temper can be added artificially (artificial temper) or was present in the initial clay (natural temper) (Maggetti 1982). According to Maggetti, the use of temper analysis to identify local or foreign ceramic production is a powerful method especially for coarse-grained ceramics. Petrographic analysis also focused features which allow quantifying sintering and vitrification including matrix birefringence and the amounts of pores and cements.

The bricks were further studied with a SEM. The analytical system employed was a Zeiss DSM-950 equipped with a backscatter electron detector and a LINK-QX 2000 energy dispersive X-ray microanalysis attachment. Spectrums were taken with a voltage of $20 \mathrm{kV}$. through a beryllium window. The SEM provides information on firing temperatures based on the existence of glass phase, which increases with the firing temperature and the duration of the firing (Tite et al. (1982)) ${ }^{1}$; Freestone \& Middleton (1991)). Qualitative elemental analyses of specific crystals and brick matrix were obtained with the EDX attachment. The major advantage of the SEM when compared to other methods for the study of ancient ceramic technologies is that it provides information on both the extent of vitrification and the firing temperature (Maniatis \& Tite, 1978). 


\section{RESULTS}

\section{Visual examination}

Forty-seven brick samples were removed from the building during conservation works. The bricks display some of the most typical features of the hand-moulded range including a great variability in size and colour (ranging from red and orange to pink and brown), uneven surfaces and edges and moulding striae. Physical properties such as hardness and cohesion also vary. The bricks display a coarse matrix with sand, very coarse sand and occasional pebbles of variable nature. Other distinctive features are a significant macroporosity and the presence of occasional cracks, reduction areas, black cinder-like inclusions and black core.

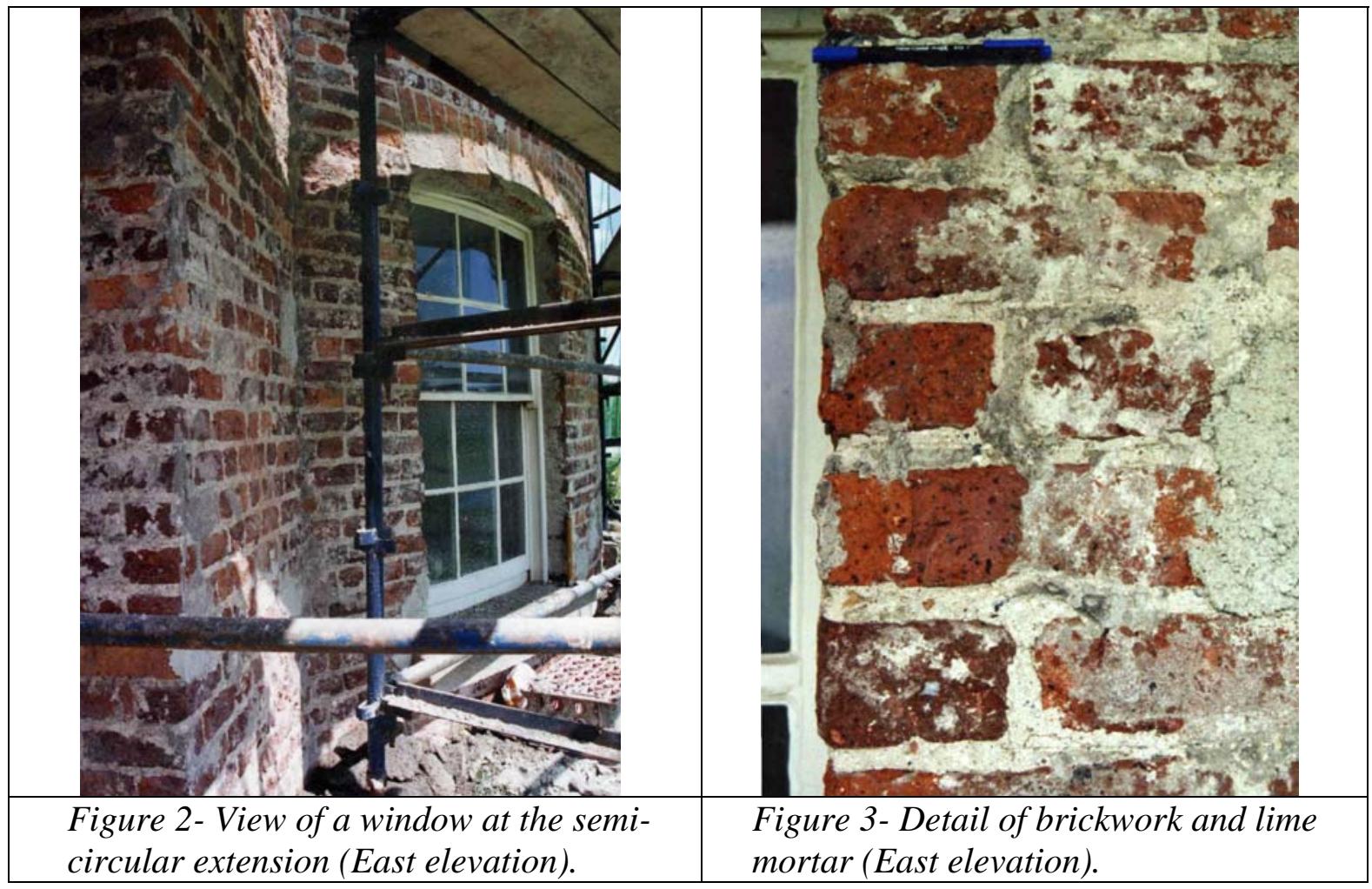

\section{$X$-ray diffraction analysis}

Table 1 includes a summary of the mineral assemblage in the brick and the local fired clay obtained by XRD analysis. According to these results, the Rathfarham brick is an, occasionally calcareous, predominantly siliceous material that includes a significant amount of quartz and feldspar (both Kfeldspar and plagioclase). Quartz is a major constituent of both the brick and the fired clay. This result was expected, as quartz is a major constituent of all brick clays. Feldspar and plagioclase accounted for over $7 \%$ of the total mineralogy in all samples analysed. Calcite, diopside, high temperature silica (probably mullite), muscovite, hornblende and spinel were occasionally recorded. All bricks, except for sample Ra 42, contained hematite in amounts varying between approximately 7 and $15 \%$. 
The mineralogy of the samples evidenced that both the brick and the local clay are predominantly non-calcareous and therefore do not develop distinctive mineral associations during firing, showing a lack of diagnostic minerals. However, the brick occasionally contains traces of primary calcite and secondary calcium silicates (diopside-wollastonite).

Approximately $70 \%$ of the bricks analysed contain traces of illite. Other phyllosilicates including chlorite, and, probably, mixed layer clays were occasionally recorded. Further experiments are needed in order to determine the exact phyllosilicate and clay mineral assemblage. However, identification may not be possible as thermal treatment causes the clay minerals to change their crystalline lattice arrangement towards a more or less amorphous transient phase and, consequently, X-ray diffraction analysis, which relies on three-dimensional lattice order, cannot be applied in this transition region (Heinmann 1982). Frequently, in the XRD trace, no characteristic X-ray diffraction peaks can be observed although a broad hump is usually present at $2 \theta=9.05$ 9.38 probably reflecting thermally treated clay.

\section{Firing experiments with local clay}

According to the firing experiments, the colour is temperature dependent: increasing the temperature turns the clay into a red shade and darkens the colour (at 700 and $800^{\circ} \mathrm{C}$ the clay displays an orange to light red colour whereas above $900^{\circ} \mathrm{C}$ it turns into a deeper red colour). This is probably due to an increase in the amount of newformed hematite as the temperature rises.

According to the XRD results in table 1, the clay fired below $900^{\circ} \mathrm{C}$ contains traces of clay minerals and minor amounts of muscovite. The latter decreases as the temperature rises, and this trend is probably coupled to an increase in the amount of feldspar. Furthermore, the clay fired at $900^{\circ} \mathrm{C}$ and above shows a lack of clay minerals while the clay fired at $1200^{\circ} \mathrm{C}$ includes abundant plagioclase, significant hematite and traces of high temperature quartz. The most relevant mineralogical changes during firing are therefore the breakdown of mica (starting at $900^{\circ} \mathrm{C}$ ), the appearance of significant hematite and feldspar above $900^{\circ} \mathrm{C}$ and the disappearance of clay minerals above $800^{\circ} \mathrm{C}$. The breakdown of mica at $900^{\circ} \mathrm{C}$ is probably associated with the increase of K-feldspar, also at $900^{\circ} \mathrm{C}$, decreasing again above $1200^{\circ} \mathrm{C}$. No amphibole, calcite or calcium silicates were recorded in the fired clay. 
Table 1- A summary of mineral assemblages of the Rathfarham brick and the local fired clay determined by XRD. Abundant: $>40 \%$; subsidiary: $40-15 \%$; minor:15-7\% ; trace: $<7 \%$.

\begin{tabular}{|c|c|c|c|c|c|c|c|c|c|c|c|}
\hline \multirow[b]{2}{*}{$\begin{array}{c}\text { Sample } \\
\text { or } \\
\text { sample } \\
\text { group }\end{array}$} & \multirow{2}{*}{$\begin{array}{l}\text { Sample } \\
\text { type }\end{array}$} & \multicolumn{10}{|c|}{ Mineralogy } \\
\hline & & $\begin{array}{l}\mathrm{Q} \\
\mathrm{U} \\
\mathrm{A} \\
\mathrm{R} \\
\mathrm{T} \\
\mathrm{Z} \\
\end{array}$ & $\begin{array}{l}\text { K- } \\
\text { F } \\
\text { E } \\
\text { L } \\
\text { D } \\
\text { S } \\
\text { P } \\
\text { A } \\
\text { R }\end{array}$ & $\begin{array}{c}\mathrm{Na}-\mathrm{Ca} \\
\text { P } \\
\text { L } \\
\text { A } \\
\text { G } \\
\text { I } \\
\text { O } \\
\text { C } \\
\text { L } \\
\text { A } \\
\text { S } \\
\text { E }\end{array}$ & $\begin{array}{c}\mathrm{I} \\
\mathrm{L} \\
\mathrm{L} \\
\mathrm{I} \\
\mathrm{T} \\
\mathrm{E}\end{array}$ & $\begin{array}{c}\mathrm{M} \\
\mathrm{U} \\
\mathrm{S} \\
\mathrm{C} \\
\mathrm{O} \\
\mathrm{V} \\
\mathrm{I} \\
\mathrm{T} \\
\mathrm{E}\end{array}$ & $\begin{array}{l}\mathrm{C} \\
\mathrm{A} \\
\mathrm{L} \\
\mathrm{C} \\
\mathrm{I} \\
\mathrm{T} \\
\mathrm{E}\end{array}$ & $\begin{array}{l}\mathrm{D} \\
\mathrm{I} \\
\mathrm{O} \\
\mathrm{P} \\
\mathrm{S} \\
\mathrm{I} \\
\mathrm{D} \\
\mathrm{E}\end{array}$ & $\begin{array}{l}\text { M } \\
\text { U } \\
\text { L } \\
\text { L } \\
\text { I } \\
\text { T } \\
\text { E }\end{array}$ & $\begin{array}{l}\mathrm{H} \\
\mathrm{E} \\
\mathrm{M} \\
\mathrm{A} \\
\mathrm{T} \\
\mathrm{I} \\
\mathrm{T} \\
\mathrm{E}\end{array}$ & $\begin{array}{l}\mathrm{S} \\
\mathrm{P} \\
\mathrm{I} \\
\mathrm{N} \\
\mathrm{E} \\
\mathrm{L}\end{array}$ \\
\hline RA 11 & Brick & $>40$ & $<7$ & $40-15$ & $<7$ & - & - & - & - & $15-7$ & - \\
\hline RA 29 & Brick & $>40$ & $15-7$ & $15-7$ & $<7$ & - & $15-7$ & - & - & $<7$ & - \\
\hline RABI 32 & Brick & $>40$ & $15-7$ & $15-7$ & $<7$ & - & $<7$ & $<7$ & - & $<7$ & - \\
\hline RABI 33 & Brick & $>40$ & - & $15-7$ & $?$ & - & $<7$ & - & $<7 ?$ & $15-7$ & - \\
\hline RA 36 & Brick & $>40$ & - & $40-15$ & $<7$ & - & - & - & & $15-7$ & - \\
\hline RA 42 & Brick & $>40$ & - & $40-15$ & - & - & - & - & $<7$ & - & $<7$ \\
\hline RATH & Brick & $>40$ & - & $40-15$ & - & - & $<7$ & - & $<7$ & $15-7$ & $<7$ \\
\hline RA700 & $\begin{array}{l}\text { Clay fired at } \\
700^{\circ} \mathrm{C}\end{array}$ & $>40$ & $<7$ & $15-7$ & $<7$ & $15-7$ & - & - & - & - & - \\
\hline RA800 & $\begin{array}{c}\text { Clay fired at } \\
800^{\circ} \mathrm{C}\end{array}$ & $>40$ & $<7$ & $15-7$ & $<7$ & $15-7$ & - & - & - & - & - \\
\hline RA900 & $\begin{array}{c}\text { Clay fired at } \\
900^{\circ} \mathrm{C}\end{array}$ & $>40$ & $15-7$ & $15-7$ & - & $<7$ & - & - & $<7$ ? & - & - \\
\hline RA1000 & $\begin{array}{c}\text { Clay fired at } \\
1000^{\circ} \mathrm{C}\end{array}$ & $>40$ & $15-7$ & $15-7$ & - & - & - & - & - & $15-7$ & - \\
\hline RA1200 & $\begin{array}{c}\text { Clay fired at } \\
1000^{\circ} \mathrm{C}\end{array}$ & $>40$ & - & $40-15$ & - & - & - & - & $<7$ & $15-7$ & - \\
\hline
\end{tabular}




\section{SEM and EDX analysis}

In order to estimate the firing temperature, the extent of vitrification of the brick was analyzed with a SEM (Tite et al. $\left.(1982)^{1}\right)$. A number of fracture surfaces showed an open texture with loose particles, a flaky structure and a high intergranular porosity (figures 4 and 5), features typically found in sedimentary materials suggesting a lack of vitrification and, therefore, low firing temperature. Approximately $25-30 \%$ of the bricks showed no vitrification. However, the number of specimens displaying local melting and welding was significant and, in some instances, the degree of particle interconnection was important, suggesting an increase in firing temperature. Several fractures display continuous glass and bloating pores indicating strong vitrification (figure 6). The bricks locally exhibit isolated smooth areas or filaments of glass, structure referred to as initial vitrification stage -IV- by Maniatis \& Tite (1981), alternating with more extensive vitrification. According to these authors, the isolated glassy areas of stage IV increase until they coalesce to form an essentially continuous vitrified layer known as the continuous vitrification stage.

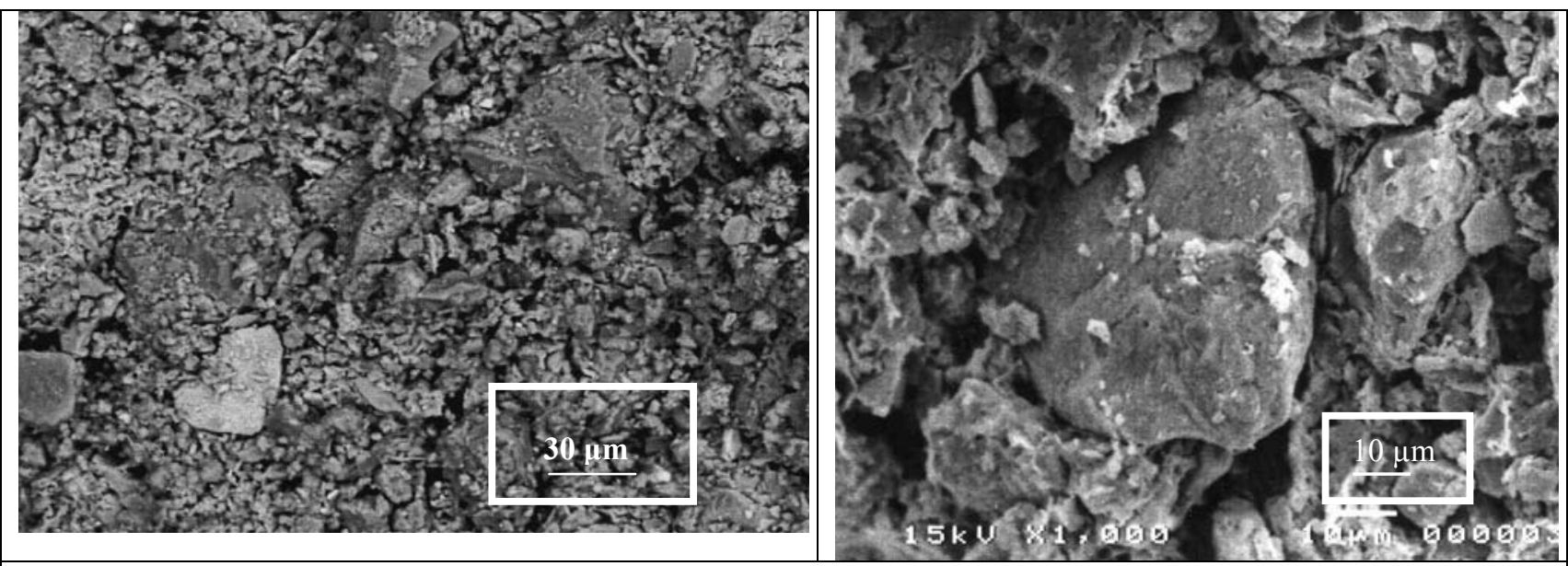

Figures 4 and 5- SEM images of bricks showing quartz and mica grains in a flaky matrix with loose particles and significant intergranular porosity, features typically found in sedimentary materials which suggest low firing temperatures.

Under the SEM, the cinder-like inclusions of the Rathfarham brick include glassy areas associated to bloating pores (figure 6) and octahedral crystals (figure 7) whichaccording to EDX analysis-consist almost entirely of $\mathrm{Fe}$. The morphology and composition of these crystals suggest that they are spinels, probably magnetite $\left(\mathrm{Fe}_{3} \mathrm{O}_{4}\right)$ or jacobsite ( $\mathrm{Mn} \mathrm{Fe}_{2} \mathrm{O}_{4}$ ) (Firman 1999 pers.com.).
The EDX analyses confirmed the XRD results, indicating the presence of abundant quartz as well as feldspar and muscovite. EDX analysis of the brick matrix showed typical elemental compositions of $\mathrm{Si}$ and $\mathrm{Al}$ with smaller amounts of $\mathrm{Mg}, \mathrm{Na}, \mathrm{Fe}, \mathrm{K}, \mathrm{Ca}$. Elemental compositions of scanned areas of the brick matrix continuously showed the presence of $\mathrm{Fe}$. 


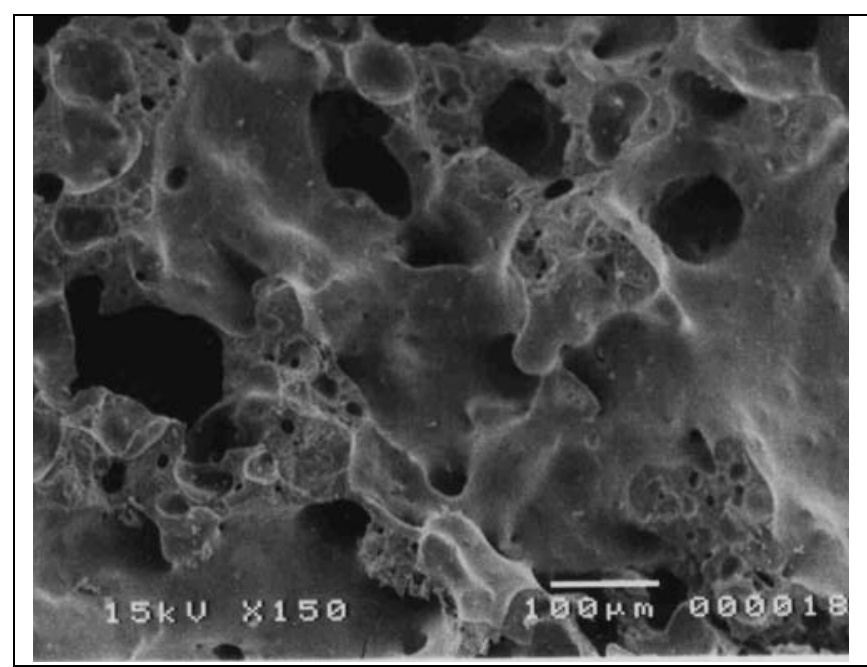

Figure 6- SEM image of a continuous vitrified layer locally exhibiting bloating pores, features indicating an increase in firing temperature.

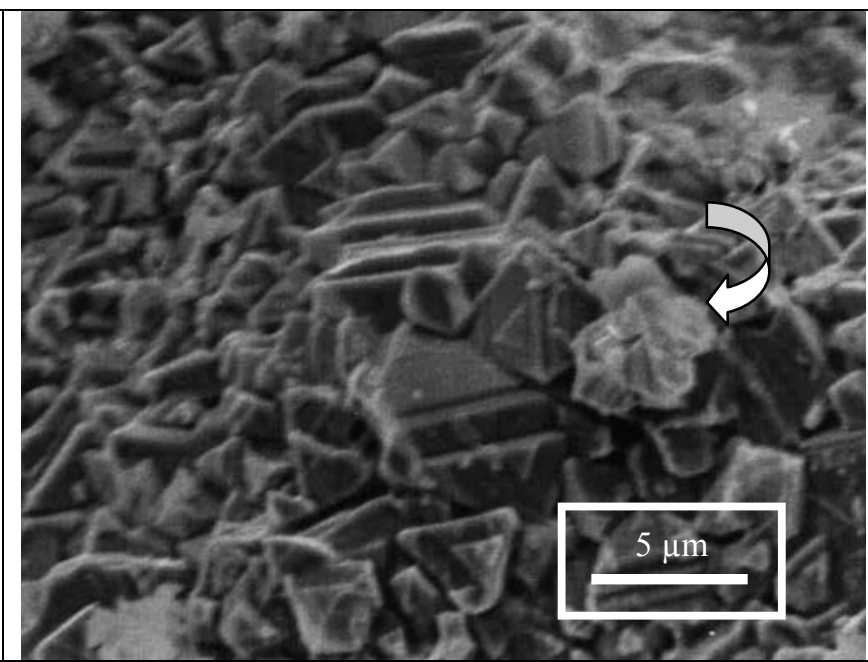

Figure 7- SEM image of a cinder inclusion including octahedral crystals of spinel, probably magnetite. A cluster of pseudo-hexagonal crystals of hematite is marked with an arrow.

\section{Petrographic microscopy}

The brick contains a high proportion of nonplastic material. Much of this material consists of rock fragments of variable nature including chert, quartzite, granitic rocks, limestone, sandstone, shale as well as sharp, both sand-graded and coarser metamorphic quartz, feldspar and muscovite. Most of these are thermally resistant relict phases remnant of the raw sediment used for brick making. However, partially transformed fragments of limestone and sandstone; overgrown quartz and feldspar; transformed muscovite and newformed feldspar, diopside, hornblende and andalusite were also detected with petrographic analysis.

Changes in the ceramic fabric due to firing were evident under the microscope. There is significant variation in the petrography of the bricks, with some petrographic fabrics suggesting low and others high temperature. Some bricks include abundant sand-grade quartz, feldspar, mica and rock fragments in a birefringent porous matrix therefore suggesting low temperature (figure 8 ), while in other bricks the ceramic body has begun to sinter and vitrify. These bricks display features indicating higher temperatures including a low-porosity, opaque matrices and both transformed and newformed minerals (figure 9).

Petrographic analysis revealed occasional fragments of fossiliferous limestone including sponge spicules, crinoids and small foraminiferae (figure 10), fossils typically found in the Carboniferous limestones of the Dublin district (Marchant and Sevastopulo, 1980). Limestones were often transformed (figures 10 and 11), containing diopside and wollastonite newformed with calcium released by the breakdown of calcite during firing (figures 12 and 13$)$. 


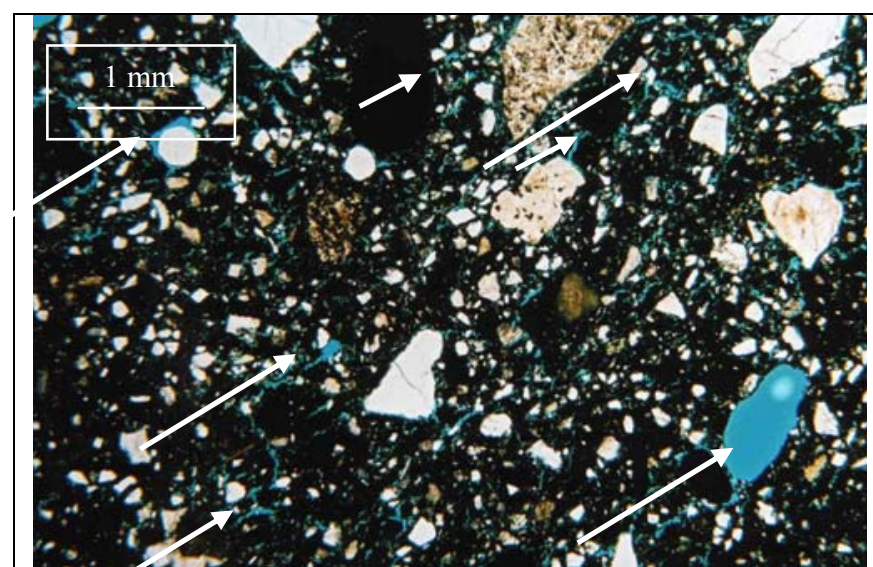

Figure 8-Characteristic petrographic fabric of a low-temperature brick: Non-transformed temper in a fractured, porous matrix (some pores marked with arrows). X 2. Plane polars.

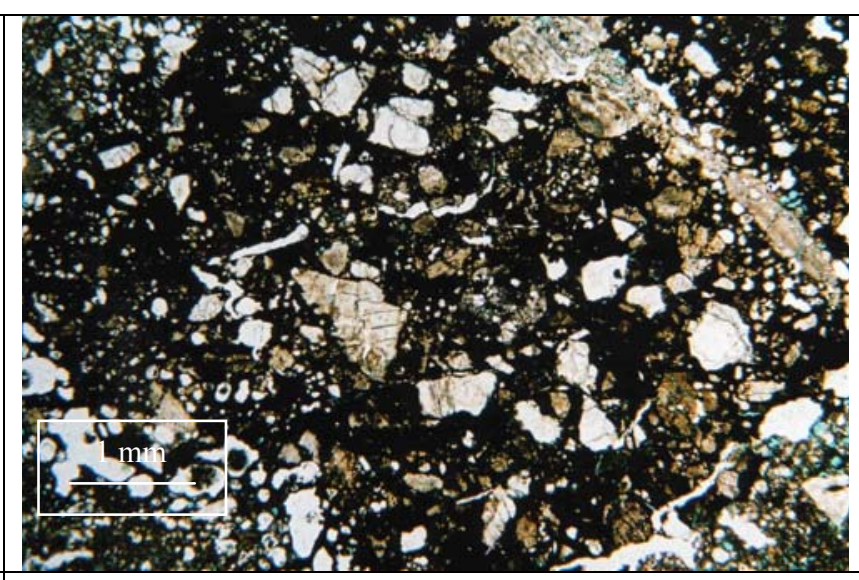

Figure 9- Petrographic fabric of hightemperature brick with a low-porosity, isotropic matrix and newformed quartz (long segregated phases). X 2. Plane polars.

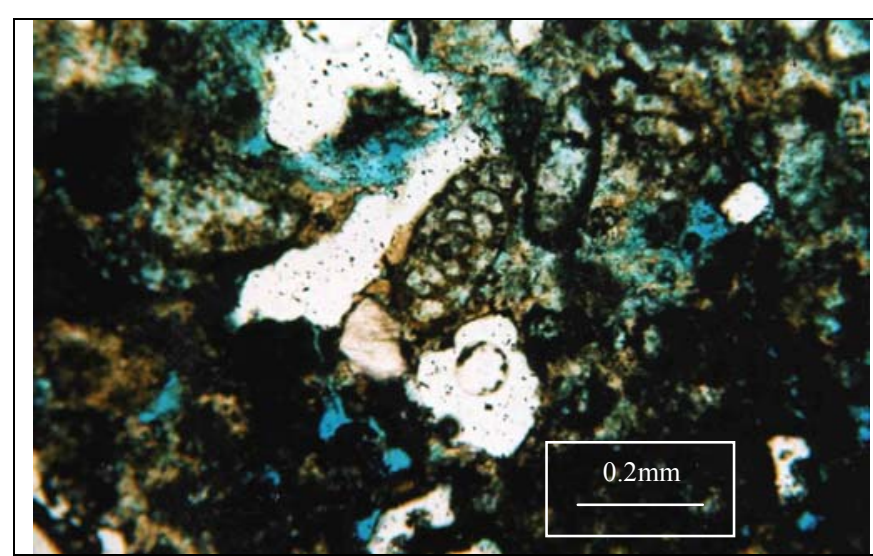

Figure 10- Detail of limestone in figure 12 showing the remains of a foraminiferae fossil. $X 10$, plane polars.

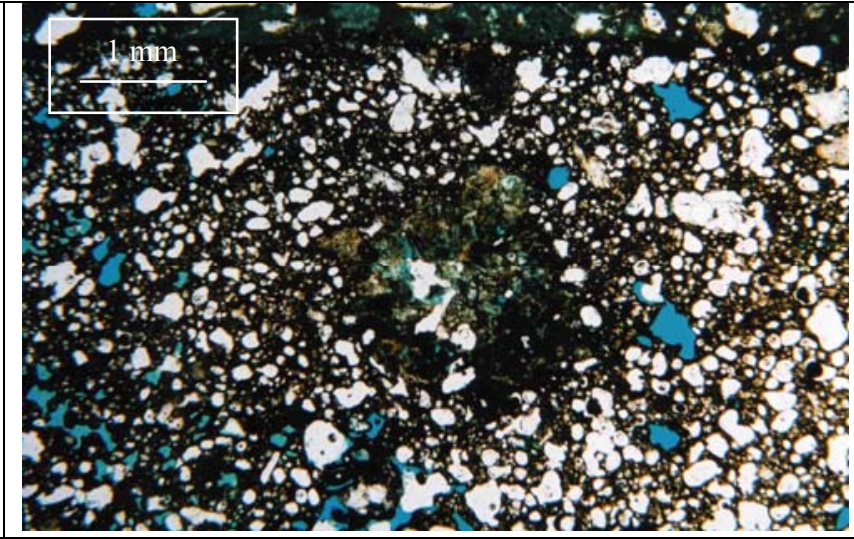

Figure 11- Brick with abundant quartz and a limestone fragment transformed during firing (centre). X 2, plane polars.

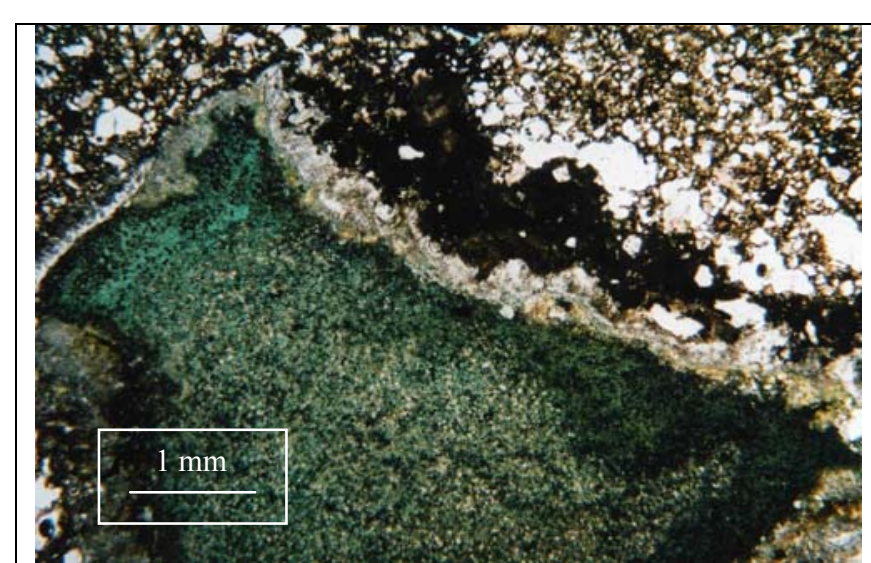

Figure 12- Transformed fragment of carbonate rock with a peripheral reaction rim where diopside and wollastonite have formed during firing. $X 2$, plane polars.

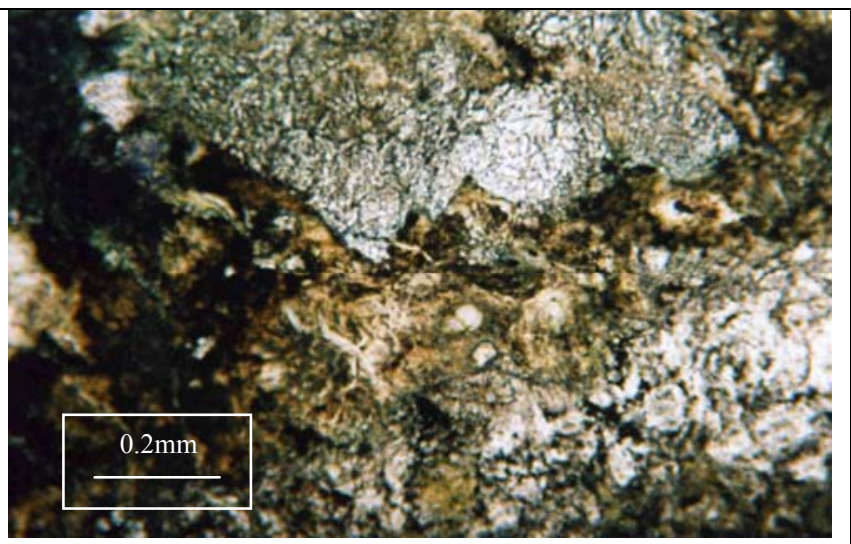

Figure 13- Detail of newformed diopside and wollastonite in reaction rim from previous image. X10, plane polars. 
Transformation of feldspar was also evident, with overgrowths and segregated phases to feldspar grains. Chert was also transformed by firing, either appearing partially replaced by hematite and opaques or showing reaction of peripheral microcrystalline silica with the adjacent matrix. Sandstone matrix and cements were occasionally replaced by euhedral hematite as a result of firing. Under the petrographic microscope, the cinder-like inclusions display sharp contacts with the surrounding matrix and consist of an isotropic material that includes both quartz and hematite (figure 14).
In order to gather further evidence of ceramic provenance, the petrography of the masonry mortar was compared to that of the brick. Several samples of lime mortar pointing the brick masonry were analysed with a petrographic microscope. The mortar consists of aggregate of variable composition including chert, quartz, feldspar, mica, quartzite, granite, sandstone, shale and other rock fragments in a porous, carbonated lime binder (figure 15).

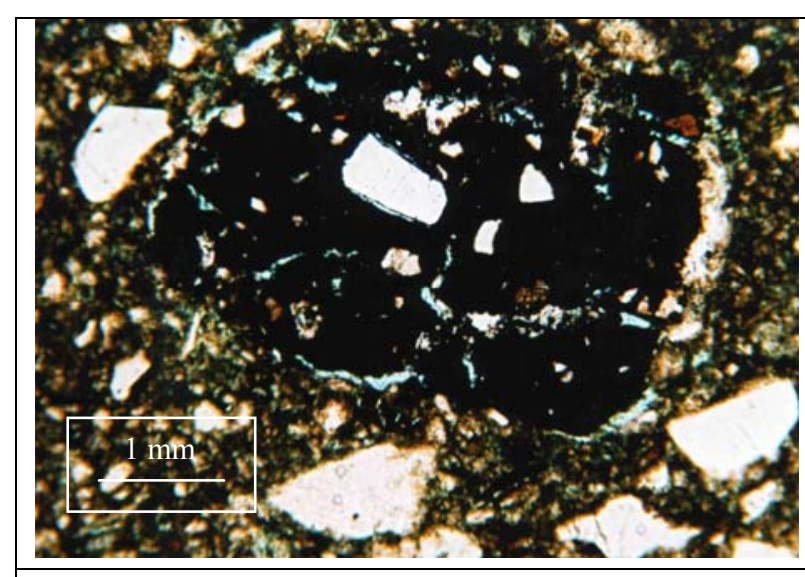

Figure 14- Microphotograph of a cinder-like inclusion consisting of quartz, segregated silica and hematite in an isotropic matrix. $X$ 2, plane polars.

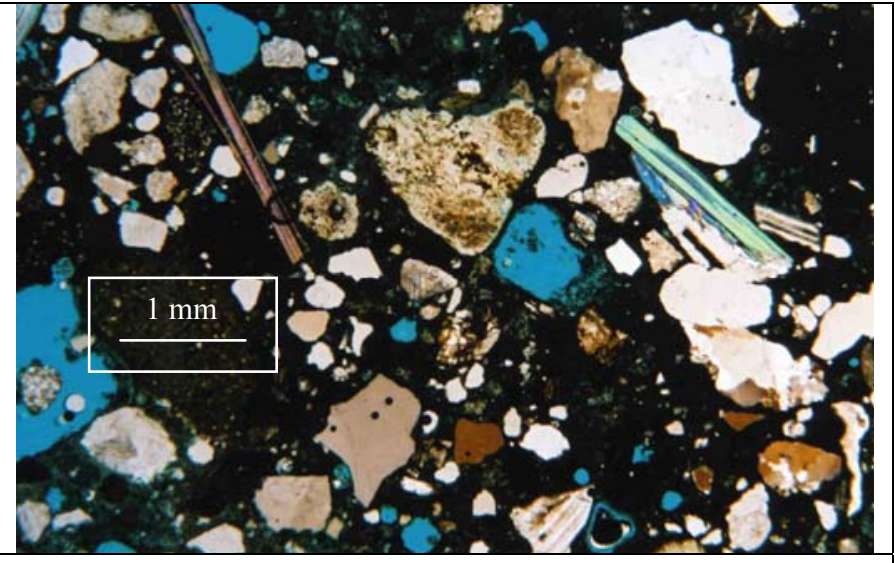

Figure 15- Microphotograph of the brick pointing mortar including chert, quartz, feldspar, mica, quartzite, sandstone, granite, shale and other rock fragments. $X 2$, crossed polars.

\section{DISCUSSION}

\section{Brick provenance}

The Rathfarham brick was probably made with a clay gathered locally. Several results support this theory. On one hand, petrographic analysis of the brick evidenced the presence of the Carboniferous limestones of the Dublin district. In addition, the rock fragments in the brick are consistent with the geology of the Dublin area therefore supporting a local source. Furthermore, the petrography of the original brick pointing mortar is consistent with that of the brick, and the petrography of the Rathfarham brick is in turn consistent with that of other contemporary bricks made with glacial clay near Dublin (Pavía and Roundtree 2005). 
A further argument supporting a local origin is that, according to the results obtained, the clay used to make the Rathfarham brick was probably gathered from a glacial deposit, and stoney boulder clays of glacial origin are common in the Dublin area. According to Firman et al. (1994) a sandy matrix including very coarse sand and occasional pebbles is characteristic of boulder clays or silty terrace gravels derived from boulder clays. The high proportion of non-plastic material in the Rathfarham brick together with the significant hematite content determined with EDX, XRD and petrographic analysis are consistent with those features of brick made with boulder clay. Besides, clast and XRD analysis of Dublin's glacial clay has shown a mineralogy similar to that of the Rathfarham brick including $80-90 \%$ Carboniferous limestone, $7-13 \%$ sandstone as well as chlorite, ilite, quartz and calcite, organic matter and iron-rich clay minerals (Farrell et al. 1995).

An additional argument to support local production is that the mineralogical assemblage and colour of the brick are similar to those of the local clay fired in the laboratory. The main difference consists in the occasional occurrence of calciumbearing minerals in the brick. However, it was revealed by petrographic microscopy that these minerals occur in coarse rock fragments (calcite in limestone and calcium silicates in transformed rock fragments). This explains their absence in the fired clay, as the clay was sieved and rock fragments removed before it was fired.

\section{Processing of the raw clay}

The presence of abundant pebbles in the brick suggests a lack of preparation of the raw clay (the clay was not sieved before it was fired). However, the results of this study suggest that the black, round, cinder-like inclusions in the brick are the remains of burned organic fuel. This would indicate some degree of preparation, probably consisting of blending the clay with fuel before firing. The presence of newformed spinel, glass and bloating pores determined by SEM, EDX and petrographic analysis suggest that the black inclusions are the remains of organic fuel. Fuel additions would have locally induced fast heating rates, high temperatures and reducing conditions causing local melting and the production of glass and spinel in 'hot spots' which reached a temperature superior to that of the surrounding matrix (spinels form above $900^{\circ} \mathrm{C}$ ). The presence of bloating pores also agrees with the inclusions being fuel additions as, on the basis of laboratory experiments, bloating is indicative of a fast heating rate, and firing in reducing atmospheres results in the development of a high concentration of fine bloating pores (Maniatis \& Tite, 1981). The regular distribution of the cinder-like inclusions and their sharp boundaries also suggest that they originate fro $0 \mathrm{~m}$ the addition of combustible matter. This agrees with historic records of coal, wood, cinder and ashes being added to the raw clay to assist firing frequently causing dark, cindery spots in the fired brick (Firman, 1994). According to Firman, easily fluxed carbonate ironstones or pyrite may also cause cinder inclusions in ceramic ware. Pyrite occurs as an accessory mineral in the Dublin's Carboniferous limestone and the adjacent Leinster Granite. Nevertheless, in the Rathfarham brick, pyrite is not responsible for the cinder-like inclusions as these are too regular, abundant and sharpedged to be due to the combustion of this mineral. Furthermore, pyrite was found to be responsible for black core and reduction areas in the brick (see below). 


\section{Colour}

Shades of red predominate in the Rathfarham brick, with occasional patches of different colour. Several authors have investigated the factors responsible for the colour of brickclays. It is generally accepted that red or brown colour is due to the presence of finely-grained ferric iron oxide (hematite) either inherited from the sediment or formed during firing, in an oxygen-rich atmosphere, from iron-bearing minerals in the raw clay. In the brick studied, the continuous presence of $\mathrm{Fe}$, mainly in the form of hematite, determined with EDX, $\mathrm{XRD}$ and microscopy agrees with the above confirming that the colour is due to the hematite content. According to Firman (1994), patches of different colour are due to primary inhomogeneities, and their size and shape depend on the character of the brickmaking sediment and the efficiency with which it was subsequently mixed and ground. Therefore, the colour inhomogeneities in the Rathfarham brick suggest a lack of mixing and grounding. This agrees with the lack of preparation of the raw clay deduced from the presence of abundant pebbles in the brick.
Petrographic examination evidenced that black core and reduction areas are related to the presence of pyrite. Black core is due to the reduction of iron in local areas where sulphur was unable to escape (Dunham 1992; Harding et al. 1962). As aforementioned, pyrite is present in the Rathfarham brick and its dissociation (between 300 and $600^{\circ} \mathrm{C}$ ) and subsequent emission of sulphurous gases caused diffuse dark areas associated to vitreous black spots (produced by remaining ferrous oxide) in the brick.

The firing and XRD analyses of the local clay evidence that increasing the temperature turns the clay into a red shade and darkens the colour as the amount of newly formed hematite rises. This agrees with the fact that the mineral assemblages of the darker bricks are those indicating higher temperatures including a high amount of hematite (over $7 \%$ ) which is sometimes associated to an increase in the amount of feldspar and the disappearance of clay minerals.

\section{Firing temperature}

The brick was made with a silica-based, predominantly non-calcareous, raw clay which produced scarce diagnostic minerals when fired. The lack of diagnostic minerals together with the variability of the material makes it difficult to establish a firing temperature range. However, rough firing temperature estimates deduced from petrographic, SEM and XRD analyses as well as firing experiments are discussed below.
Petrographic analysis evidenced firing temperatures of, at least, $850^{\circ} \mathrm{C}$, based on the presence of transformed limestone and newformed diopside and wollastonite: 'calcite decomposes at approximately $600-$ $850{ }^{\circ} \mathrm{C}$ in a natural clay, and the calcium silicates diopside-wollastonite appear in the range 850 - $900{ }^{\circ} \mathrm{C}$ ' (Peters et al., 1978; Maggetti, 1982). 
SEM analyses suggest top firing temperatures of $750-950 \mathrm{C}^{\circ}$. The bricks locally exhibit the isolated glass filaments characteristic of the initial vitrification stage (IV) as well as the continuous vitrified stage (CV). According to Tite et al. $1982^{2}$, the IV is developed at firing temperatures of $750-800^{\circ} \mathrm{C}$ (for noncalcareous clays in an oxidizing atmosphere), and a temperature range of $150^{\circ} \mathrm{C}$ separates the IV stage from the CV stage. However, it is possible that the Rathfarham brick exhibits the IV stage after firing to $800-850^{\circ} \mathrm{C}$ due to the low refractoriness of its raw clay: 'in an oxidizing atmosphere, low refractory, noncalcareous clay (containing between 10 and $20 \%$ of fluxes and less than 5\% calcite) exhibits the IV stage after firing to 800$850^{\circ} \mathrm{C}^{\prime}$. (Maniatis \& Tite, 1978 ).

The mineral assemblages determined with XRD suggest that some bricks probably reached top temperatures in excess of $900^{\circ} \mathrm{C}$. According to Dunham (1992), clay minerals begin to form new silicates at approximately $900^{\circ} \mathrm{C}$ (mullite and spinel form at $900^{\circ} \mathrm{C}$ ), while Veniale (1994) states that spinel can develop from kaolinite, illite, mixed-layer clays or montmorillonite at a temperature ranging between 850 and $1000^{\circ} \mathrm{C}$. However, the presence of fluxes may have altered the resultant brick mineralogy as these generate a fluid phase which is responsible for the enhancement of reaction kinetics and for the increase of 'chemical communications' among reacting phases (Diminuco et al. 1998). The temperatures above refer to the behaviour of pure minerals while, in contrast, the raw clay used to make the Rathfarham brick was a complex sediment containing lime, feldspar (alkalis $\mathrm{Na}$ and $\mathrm{K}$ ) and ferrous oxide, and it is possible that these locally lowered the onset of liquid-state sintering acting as fluxes.

As mentioned above, it was evidenced that the darker bricks, which probably reached higher temperature, contain the highest amounts of feldspar and hematite and the lowest amounts of clay minerals. This agrees with the firing experiments, which demonstrated that increasing temperature turns the clay into a darker red shade and causes the breakdown of mica (starting at $900^{\circ} \mathrm{C}$ ), an increase of $\mathrm{K}$-feldspar (also starting at $900^{\circ} \mathrm{C}$ to decrease above $1200^{\circ} \mathrm{C}$ ), the appearance of significant hematite and plagioclase (above $1000^{\circ} \mathrm{C}$ ) and the disappearance of clay minerals (above $800^{\circ} \mathrm{C}$ ).

\section{Firing technology}

Between 25 and $30 \%$ of the Rathfarham brick showed no vitrification, and the top temperatures deduced from SEM, XRD and petrographic analyses range between 750 and $950^{\circ} \mathrm{C}$. However, these top temperatures may be overestimated due to the presence of fuel and fluxes within the raw clay, as these probably lowered the temperature necessary to obtain the mineralogical assemblage and vitrification microstructures found in the brick. 
The widespread variation in the ceramic fabric determined with SEM and petrographic techniques (ranging from areas suggesting high firing temperatures to those which have undergone very little change through firing) as well as the great variability in the physical properties of the brick including colour, hardness and cohesion, suggest a wide range of firing temperatures. This, together with the presence of non-vitrified bricks, can be associated to clamp firing. According to Tite (1995), open fires or clamps are characterized by fast heating rates and very short times at maximum temperature. 'Maximum temperatures range from $500-900^{\circ} \mathrm{C}$ with a high proportion in the range $600-800^{\circ} \mathrm{C}$ and temperature variations of several hundred degrees are observed within a single firing'. According to the same author, in kiln firing, temperature variations are more restricted, and maximum firing temperatures span the range from 600 to $1000^{\circ} \mathrm{C}$, with a high proportion in the range $750-950^{\circ} \mathrm{C}$. However, effective firing temperatures ranging between
500 and $1200^{\circ} \mathrm{C}$ have also been observed in kiln firings and, here, temperature variations across the bricks are a sign of relatively short soaking times (Wolf 2002).

The presence of black core and diffuse dark areas in the brick may also relate to clamp firing. Black core results from the lack of oxidation of ferrous compounds in the centre of the brick and often arises as a result of firing in reducing atmosphere, due to the presence of organic matter or sulphur within the clay or as a result of ceramic ware kept in contact with the fuel used for firing (Firman et al. 1964). According to Tite (1995), the firing atmosphere in open fires can change rapidly from reducing to oxidizing subject to fluctuations in wind and weather, and the ware is only very rarely fully oxidized, because it is in intimate contact with fuel and there is insufficient firing time for organic material within the clay to be burnt out.

\section{CONCLUSION}

The Rathfarham brick was made with a silica-based, predominantly non-calcareous boulder clay including a high percentage of non-plastic material. Raw clays are usually referred to as calcareous or non-calcareous. However, the raw clay used to make the Rathfarham brick has elements of both, as the matrix is generally non-calcareous and the brick occasionally includes limestone fragments. The presence of pebbles and colour inhomogeneities in the brick suggest a lack of preparation of the raw clay however, the presence of newformed spinel, glass and bloating pores whithin the cinderlike inclusions in the brick suggest that the clay was probably blended with combustible organic matter before it was fired. The predominantly red colour of the brick is due to the hematite content while the black core and reduction areas are related to the presence of pyrite.

The presence of fragments of local rocks in the brick and the similarities between the mineralogical assemblage and colour of the brick and those of the local fired clay suggest a local origin for the brick. Furthermore, the petrography of the original masonry mortar matching that of the brick, together with the fact that the brick was made with a boulder clay of glacial origin similar to those in the Dublin area further support a local source. Finally, the petrography of the Rathfarham brick being consistent with that of other contemporary bricks made with glacial clay near Dublin reinforces the possibility of a local origin. 
It can be concluded that approximately one third of the bricks showed no vitrification, and the maximum temperatures deduced from SEM, XRD, petrographic analysis and firing experiments range between 750 and $950^{\circ} \mathrm{C}$. These maximum temperatures may be overestimated due to the presence of fuel and fluxes within the raw clay, as these have probably produced fluid phases responsible for the enhancement of reaction kinetics and mineral reactivity, lowering the temperature necessary to obtain the mineralogical assemblages and vitrification microstructures found in this study. The wide range of firing temperature suggested by the widespread variation of the ceramic fabric and physical properties together with the presence of non-vitrified bricks, black core and reduction areas are possibly associated to both clamp firing and the presence of fuel and fluxes in the raw material used to make the brick.

\section{Acknowledgements}

The author would like to thank Dr Ron Firman, University of Nottingham, UK, for his suggestions and for reviewing the results of the research on which this paper is based. This research work was funded by National Monuments, Department of the Environment and Local Government. The author would like to thank Mr Paul McMahon, Senior Conservation Architect of the aforementioned Department, for supporting the research project in a variety of ways. The author would also like to thank Mr. Gay Daly for his drawings of Rathfarham Castle; Dr. Lynch, Prof. Tite, Prof. Maggetti and Prof. Veniale, for providing bibliographical references for this work; Mr. John and Sarah Turner, of Storecore for their thin sections; Mr. Colin Reid, Mr. Neil Leddy and Mr. David John, of the Centre for Microscopy and Analysis, Trinity College Dublin, for their assistance with the SEM analysis and Ms. Ana Read, Faculty of the Built Environment, DIT, for her help with the firing experiments.

\section{References}

Dunham, A.C., 1992, Developments in Industrial Mineralogy: I. The mineralogy of brickmaking, Proceedings of the Yorkshire Geological Society, 49, part 2, 95-104.

Diminuco, P. Messiga B. and Riccardi M.P., 1998, Firing process of natural clays. Some microtextures and related phase compositions, Thermoquimica Acta, 321, 185-190.

Farrell, E.R., Coxon, P., Doff, D.H., Pried'homme, L., 1995, The genesis of the brown boulder clay of Dublin, Quaterley Journal of Engineering Geology, 28, 143-152.

Firman, R.J. and Firman P.E. 1967 A geological approach to the study of medieval bricks. Mercian Geologist 2 (3), 299-318.

Firman, R.J. 1994 The colour of brick in historic brickwork. British Brick Society Information 61, 3-9. 
Freestone, I.C. \& Middleton, A.P., 1991, Mineralogical Applications of the analytical SEM in archaeology, Mineralogical Magazine, 51, 21-31

Freestone, I.C., 1995, Ceramic Petrography, American Journal of Archaeology, 99, 111-115

Harding J. R., Robinson J.S., Rowden E. and Coe, A., 1962, in Brickwork Kilnburners Course. The Brick Development Association and the College of Fuel Technology.

Heimann, R.B., 1982, Firing technologies and their possible assessment by modern analytical methods, in Archaeological ceramics (ed. J. S. Olin \& A. D. Franklin), 86-96, Smithsonian Institution Press, Washington DC.

Maggetti, M., 1982, Phase analysis and its significance for technology and origin, in Archaeological ceramics (ed. J. S. Olin \& A. D. Franklin), 121-133, Smithsonian Institution Press, Washington DC.

Maggetti, M., 1994, Mineralogical and petrographical methods for the study of ancient pottery, in First European Workshop on Archaeological Ceramics, 23-35, Rome.

Maggetti, M., 1995, Méthode chimique contre méthode minéralogique pétrographique dans l'étude des céramiques anciennes, in Proceedings of the European Meeting on Ancient Ceramics, Barcelona.

Maniatis, Y. \& Tite, M.S., 1978, Examination of Roman and Medieval pottery using the scanning electron microscope, Acta praehistorica et archaeologica 9/10, 125-130

Maniatis Y. and Tite M.S., 1981, Technological examination of Neolithic-Bronze Age pottery from central and southeast Europe and from the near east. Journal of Archaeological science, 8 , $59-76$.

Marchant, T.R., Sevastopulo, G.D., 1980, The Calp of the Dublin District, Journal of Earth Science of the Royal Dublin Society, 3, 195-203.

Matson F.R., 1982, Archaeological ceramics and the physical sciences: Problem definition and results, in Archaeological ceramics (ed. J. S. Olin \& A. D. Franklin), 19-28, Smithsonian Institution Press, Washington DC.

Heimann, R.B., 1982, Firing technologies and their possible assessment by modern analytical methods, in Archaeological ceramics (ed. J. S. Olin \& A. D. Franklin), 86-96, Smithsonian Institution Press, Washington DC.

Pavía S., 1994, Material de construcción antiguo de Logroño y La Rioja Alta: petrografía, propiedades físicas, geología y alteración. Instituto de Estudios Riojanos. Logroño. 
Pavía S., 1999 ${ }^{1,}$ A comparative study of Mediaeval Irish clay brick, in, Clay Minerals Group Spring Meeting of the Mineralogical Society of Great Britain and Ireland, Trinity College Dublin.

Pavía S., $1999^{2}$, A study of $17^{\text {th }}$ century Irish clay brick, in Mineralogy of Ceramics: ancient and modern, Mineralogical Society of Great Britain and Ireland. Applied Mineralogy Group Meeting. London.

Pavía S., J. Bolton, G. Walker, P. MacMahon, T. Dunphy, $2000^{1}$, The Brick in Portumna Castle, County Galway, Ireland British Brick Society Bulletin, 80, 5-10.

Pavía S. and Bolton J., 2000², Stone, Brick and Mortar. Historical uses, decay and conservation of building materials in Ireland, Wordwell, Bray.

Pavía S. and Roundtree S., 2005, An Investigation into Irish Historical Ceramics: The Brick of Arch Hall, Wilkinstown, Co. Meath. Proceedings of the Royal Irish Academy, 105C, 6, 221-242.

Peters, T. and Iberg, R., 1978, Mineralogical changes during firing of calcium-rich brick clays, Ceramic Bulletin, 57, 5, 503-509.

Roundtree, S, 1999, History of clay brick as a building material in Ireland. Unpublished Masters thesis, Dublin Institute of Technology/Trinity College Dublin.

Veniale, F., 1990, Modern techniques of analysis applied to ancient ceramics, in Analytical methodologies for the investigation of damaged stones, Pavia, Italy.

Veniale, F., 1994, Raw materials and manufacturing processes in ancient ceramic artefacts, in First European workshop on Archaeological ceramics, Roma.

Tite, M.S., 1995, Firing temperature-How and Why?, in KVHAA Konferenser, Stockholm 1995, 34, 37-42,

Tite, M.S. and Maniatis Y., 1975, Examination of ancient pottery using the scanning electron microscope, Nature, 257, No. 5522, 122-123.

Tite, M.S.; Freestone, I.C.; Meeks, N.D.; Bimson, M., $1982^{1}$, The use of scanning electron microscopy in the technological examination of ancient ceramics, in Archaeological ceramics (ed. J. S. Olin \& A. D. Franklin), 109-120, Smithsonian Institution Press, Washington DC.

Tite, M.S.; Maniatis Y.; Meeks, N.D.; Bimson, M.; Hughes, J. and Leppard, S.C., 1982², Technological studies of ancient ceramics from the Near East, Aegean and Southeast Europe, in Early pyrotechnology (eds T.A. Wertime and S.F. Wertime), 61-71, Smithsonian Institution Press, Washington DC. 
Archaeometry 48, 2 (2006) 201-218

Wolf, S., 2002, Estimation of the production parameters of very large medieval bricks from St. Urban, Switzerland. Archaeometry, 44, 1, 37-65.

Wyse-Jackson, P., 1994, The building stones of Dublin: a walking guide. Town House and Country House. 